STUDIA 



\section{ARCHIWA OCEANII W ROKU 1984 GEORGE'A ORWELLA I ARCHIWA PZPR Próba analizy porównawczej}

\section{Słowa kluczowe}

Polska Zjednoczona Partia Robotnicza; archiwa PZPR; Rok 1984 George'a Orwella; archiwa w literaturze pięknej

\section{Keywords}

Polish United Workers' Party; archives of Polish communist party; Nineteen Eighty-Four by George Orwell; archives in belles-lettres

\section{Streszczenie}

Podobieństwo realiów rządzonego przez Partię totalitarnego państwa Oceania z Roku 1984 do rządów komunistycznych w Europie i poza nią skłania do porównań pomiędzy nimi. Pozwalają one, tak jak w przypadku mojego artykułu, na uzyskanie dodatkowej wiedzy nie tyle o owej książce, ile o wspomnianym systemie. W tym artykule skoncentrowałem się na problematyce archiwów i po części przeszłości i historii, ilustrowanej informacjami z książki George’a Orwella i z archiwaliów Polskiej Zjed-

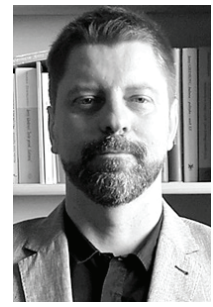

Tomasz Czarnota, doktor nauk humanistycznych, adiunkt w Zakładzie Archiwistyki i Nauk Pomocniczych Historii Uniwersytetu Marii Curie-Skłodowskiej w Lublinie. Jego zainteresowania badawcze to przede wszystkim działalność dokumentacyjna i archiwalna organizacji społecznych, politycznych oraz osób. Autor m.in. monografii To zawsze zostanie dla potomności... Archiwalia w kręgu myśli i prac Jerzego Giedroycia (Lublin 2010). Członek Towarzystwa Nauki i Kultury Libra i Kolegium Eksperckiego Ruchu Archiwów Społecznych. E-mail: tomasz.czarnota@poczta.umcs.lublin.pl. 
noczonej Partii Robotniczej. W Oceanii przeszłość była kategorią zmienną wskutek zdobycia pełnej kontroli nad wszystkimi elementami łączącymi ją z teraźniejszością (gazetami, książkami, dokumentami etc.), wiodącej do utrwalenia władzy Partii. Znajdujące się w archiwach dokumenty poddawano stałemu podmienianiu pod kątem ich zgodności z tym, co akurat twierdziła Partia. W tej sytuacji dostęp do spreparowanych opracowań i źródeł musiał być wolny. Nie było za to miejsca na obiektywną historiografię, choć wydawano książki mające uchodzić za „historyczne”. Z kolei rządząca w Polsce PZPR w dokonaniach własnych i swych ideowych poprzedniczek widziała element ważny dla jej ideologii oraz czynnik legitymizujący jej władzę. Zauważała korzyści płynące z inicjowania badań historycznych (niekoniecznie w pełni obiektywnych) oraz chronienia w swoich archiwach autentycznych dokumentów, służących prowadzeniu tychże badań i działalności propagandowej. Ale zasób jej archiwów nie był dostępny wszystkim. Reglamentacją objęte były dokumenty ilustrujące np. „niepostępowe” zjawiska. Z porównania podejścia do tych zagadnień oceańskiej Partii i PZPR wynika, że były to właściwie całkiem różne wizje i style postępowania. Wypływa stąd wniosek, że PZPR w niewielkim stopniu, jeśli chodzi o problematykę archiwalną, przypominała analogiczne wątki opisane przez Orwella.

RR ok 1984 to powszechnie znana antyutopijna powieść o totalitarnym państwie zwanym Oceanią, rządzonym przez Partię, która jako jedyne tamtejsze stronnictwo polityczne nie potrzebowała w nazwie wyróżnika. Opisane przez George’a Orwella (właśc. Erica Blaira) realia funkcjonowania Pasa Startowego Numer Jeden, niegdysiejszej Wielkiej Brytanii - jednej z prowincji owego państwa, dążącego do całkowitej likwidacji wszelkich uczuć poza strachem, wściekłością, triumfem i samoupodleniem oraz zniszczenia wszelkich więzi międzyludzkich (poza przywiązaniem do Partii), wzbudzają grozę chyba w każdym czytelniku tego ponadczasowego dzieła. Wcielany w życie przez Partię plan dalszego „rozwoju” stosunków w Oceanii przewidywał nawet zniesienie sztuki i literatury oraz nauki. Jak tłumaczył O’Brien, funkcjonariusz Wewnętrznej Partii przesłuchujący głównego bohatera książki, Winstona Smitha: „Kiedy staniemy się wszechwiedzący, nauka na nic się nam zda”. Posunięcia te miały zagwarantować Partii utrzymanie władzy po wieczność.

Panuje przekonanie, że zręby świata ukazanego przez Orwella mają bezpośrednie odniesienie do systemu rządów komunistycznych, które po II wojnie światowej objęły dużą połać Europy i innych kontynentów, a którego ekspansja, jak wielu sądziło w końcu lat 40. XX w., gdy po raz pierwszy wydano Rok 1984, miała nieuchronnie postępować. Podobieństwo, a nawet zbieżność wielu elementów tej literackiej wizji z systemem społeczno-politycznym panu-

1 G. Orwell, Rok 1984, przeł. T. Mirkowicz, Warszawa 1988, s. 184. 
jącym w krajach zagarniętych przez komunistów skłania do czynienia między nimi porównań. W tym artykule skoncentrowałem się na jednym z wątków obecnych w Roku 1984, powiązanym z profesją głównego bohatera, a także z podwalinami ustrojowymi Oceanii. Mam na myśli stanowisko Partii wobec przeszłości, a w szczególności rolę i zadania przypisane przez nią archiwom. Informacje na ten temat postanowiłem zestawić z tym, co wiadomo o podejściu do tych zagadnień beneficjentki powojennych zmian w Polsce sukcesorki Polskiej Partii Robotniczej, czyli Polskiej Zjednoczonej Partii Robotniczej (PZPR). Jej archiwalia odzwierciedlają większość przejawów życia społecznego, gospodarczego i kulturalnego w Polsce w latach 1948-1989. Spełnianie przez kierownicze struktury PZPR funkcji „superrządu”, a także jej nadrzędność we wszystkich dziedzinach życia uzasadniają traktowanie jej dokumentów na równi z aktami organów władzy państwowej² ${ }^{2}$ Pozwala to uznać zestawianie zagadnień archiwalnych odpowiednio w PZPR i w Oceanii za uprawnione. Skupiłem się na zawężonym do sfery deklaratywno-normatywnej funkcjonalnym aspekcie tej problematyki, z pominięciem szczegółowych odniesień faktograficznych dotyczących archiwów PZPR. Wariant ten wydaje mi się jedyną sensowną płaszczyzną porównania dwóch odmiennych modeli, z których jeden jest tłem znanego utworu literackiego, drugi zaś stanowi konstrukt ideologiczno-organizacyjnych poczynań rzeczywistego stronnictwa politycznego. Uprzedzając ewentualne wątpliwości czytelników tego artykułu co do tego, czy dopuszczalne jest zestawianie literackiej fikcji z realiami, wyjaśniam, że wątków zaczerpniętych z Orwella nie traktuję jako porównawczo równoprawnej warstwy faktograficznej, lecz są one dla mnie przede wszystkim punktem odniesienia, rodzajem „zwierciadła”, w którym lepiej można dostrzec poczynania PZPR na polu historyczno-archiwalnym. Dla niektórych niech pozostanie to quasi-analizą porównawczą. Zarazem chciałbym dodać, że posługiwanie się wątkami zaczerpniętymi z fikcji literackiej do opisu pewnej dziedziny rzeczywistości nie jest moim oryginalnym pomysłem. Można je zaobserwować np. w naukowych rozważaniach historiograficznych ${ }^{3}$. Egzemplifikacje składające się na opis owych modeli dobrałem z wymienio-

2 Por.: W. Horst, Kancelarie i archiwa Centralnego Komitetu Wykonawczego Polskiej Partii Socjalistycznej, Komitetu Centralnego Polskiej Partii Robotniczej i Komitetu Centralnego Polskiej Zjednoczonej Partii Robotniczej (1944-1990), Warszawa 2006, s. 231; D. Magier, Archiwum Komitetu Wojewódzkiego PZPR w Białej Podlaskiej, „Archiwa Kancelarie - Zbiory", nr 1 (3), 2010, s. 103.

3 Por. R. Stobiecki, Bolszewizm a historia. Próba rekonstrukcji bolszewickiej filozofii dziejów, Łódź 1998, s. 72. Autor, rekonstruując spojrzenie N. Bucharina na histo- 
nej książki angielskiego pisarza oraz z szeregu dokumentów PZPR wytworzonych w okresie czerech dekad jej istnienia. W dalszej części niniejszego artykułu najpierw ukażę rozwiązania, którym miała patronować oceańska Partia, następnie scharakteryzuję te, które są właściwe praktykom PZPR, a na końcu je podsumuję i przedstawię nasuwające się z dokonanych porównań wnioski.

Zagadnienia związane z przeszłością, pamięcią i archiwami w realiach Oceanii przedstawiały się z naszego punktu widzenia specyficznie. Miało to związek z dwójmyśleni e m będącym kwintesencją ideologii Angsoc, które spopularyzowano m.in. w haśle. „Wojna to pokój, wolność to niewola, ignorancja to siła", a także w przewrotnych nazwach głównych instytucji państwowych: Ministerstwo Prawdy, Ministerstwo Pokoju, Ministerstwo Miłości i Ministerstwo Obfitości. Ową specyfikę najtrafniej oddaje slogan: „Kto rządzi przeszłością, w tego rękach jest przyszłość; kto rządzi teraźniejszością, w tego rękach jest przeszłość"5. Zmienność przeszłości stanowiła, obok d wój my śle n i a i nowomowy, jedną z podstaw Angsocu ${ }^{6}$. Uwięziony w kazamatach Ministerstwa Miłości Smith, którego w czasie przesłuchania indagowano o to, w jaki sposób według niego istnieje przeszłość, gdzie - w jakim wymiarze ona egzystuje, odpowiedział, że trwa ona, tzn. jest zapisana w dokumentach i w ludzkiej pamięci. Otrzymał na to od O'Briena odpowiedź: „No dobrze. Ale my, Partia, mamy w swoich rękach całą dokumentację i my panujemy nad wspomnieniami"7. W dalszej dyskusji Smith bronił swego twierdzenia tylko odnośnie do pamięci i wspomnień zakodowanych w umyśle ${ }^{8}$. Zdawał sobie sprawę z tego, że o ile w tej sferze Partia, mimo ogromnych postępów, jeszcze nie osiągnęła triumfu (członkowie Partii musieli wciąż trenować odnoszenie ciągłych zwycięstw nad własną pamięcią) ${ }^{9}$, to w wymiarze dokumenta-

rię, odwołał się do fikcyjnej wypowiedzi bohatera jednej z książek Arthura Koestlera - M. S. Rubaszowa, którego postać była wzorowana na Bucharinie.

${ }^{4}$ G. Orwell, dz. cyt., s. 147. Emmanuel Goldstein, według Partii „wróg ludu”, w księdze jego autorstwa pt. Teoria i praktyka oligarchicznego kolektywizmu opisał je m.in. tak: „Kłamać z pełną premedytacją, a jednocześnie głęboko wierzyć we własne słowa, zapominać niewygodne fakty, po czym, gdy zachodzi konieczność, przywoływać je z niebytu na tak długo, jak trzeba, negować istnienie obiektywnej rzeczywistości, a zarazem kierować się nią - to wszystko musi umieć każdy".

${ }^{5}$ G. Orwell, dz. cyt., s. 170.

6 Tamże, s. 22.

7 Tamże, s. 170.

8 Chociaż przy braku jakichkolwiek zewnętrznych punktów odniesienia nawet zarysy jego własnego życia nie miały dla niego ostrości. Tamże, s. 26.

9 Tamże, s. 28. 
cji jej kontrola była całkowita. Najbardziej wyrazistym, choć oficjalnie nigdy nieeksponowanym przejawem kontrolowania przez nią dokumentacji i jednocześnie techniką rządzenia przeszłością było „regulowanie faktów” tożsame d w ó j m y śl e n i $\mathrm{u}^{10}$. Do tego szczególnie istotnego zagadnienia wrócę w dalszej części artykułu.

Pochodną traktowania przez Partię przeszłości był jej stosunek do dyscypliny naukowej ukierunkowanej na jej rekonstrukcję. Orwell nie napisał, czy w Oceanii uprawiano historiografię, aczkolwiek w swojej książce zawarł epizod, kiedy główny bohater sięga do szkolnego podręcznika historii ${ }^{11}$. Można wszakże założyć, że treści tego rodzaju opracowań miały(by) więcej wspólnego z apologią niż z dążącą do ustalenia prawdy obiektywną nauką historyczną lub po prostu z literaturą, która choć stanowi podobne do historiografii zjawisko z dziedziny kultury, od tej ostatniej jest oddzielona brakiem oparcia na dających się poddać weryfikacji elementach, jakimi są fakty ${ }^{12}$. Zatem, jeśli nawet byli(by) tam „specjaliści”, zapewne w Ministerstwie Prawdy, parający się swoiście pojmowaną historią, swą pracę wykonywali(by) oczywiście w zgodzie z Angsocem. To oznacza, że tamtejsze opracowania historyczne były(by) czymś zgoła odmiennym od klasycznego piśmiennictwa historycznego. Nie mogło być inaczej, skoro Partia od wszystkich żądała odrzucenia nawet zdrowego rozsądku ${ }^{13}$, doprowadzając także do wyrugowania samej świadomości tego, czym są: podejście naukowe, metody poznawcze i naukowa wiedza ${ }^{14}$. Naukę traktowano tam wybitnie instrumentalnie, a jedyne autentyczne badania były prowadzone w sferze zwiększania kontroli nad psychiką człowieka i w dziedzinie militarnej ${ }^{15}$.

W Oceanii nie było więc podstaw do uprawiania historiografii, bodaj przede wszystkim w związku z permanentnie odbywającym się „regulowaniem faktów". Smith był w to bezpośrednio zaangażowany - jako urzędnik jednego z działów departamentu archiwów w Ministerstwie Prawdy w ramach codziennych obowiązków służbowych zmieniał treść wszelkich zapi-

10 Tamże.

11 Tamże, s. 60.

12 Zob. S. Marchel, „Przez dziurke od klucza...” Rozważania na marginesie badań nad rola archiwów $w$ procesie kształtowania interpretacji historycznej, [w:] Otwarty skarbiec pamięci. Studia Zespołu Archiwum Państwowego w Opolu zebrane z okazji 60-lecia powstania instytucji, cz. 2: Bogactwo zasobu i przygoda poznania, red. M. Lenart, Opole 2013, s. 9.

13 G. Orwell, dz. cyt., s. 60.

14 Tamże, s. 214-215.

15 Tamże, s. 136. 
sów z przeszłości odpowiednio do aktualnej linii politycznej i prognoz Partii. Tak rozumianym „regulowaniem” były objęte wszelkie dokumenty i utwory: książki, czasopisma, plakaty, ulotki, filmy, nagrania, rysunki, fotografie - każdy typ literatury i dokumentacji o jakimkolwiek znaczeniu politycznym lub ideologicznym ${ }^{16}$. Smith starał się przy tym, aby jego fałszerstwa były jak najdoskonalsze, co dawało mu satysfakcję „z dobrze wykonanej pracy”, choć jednocześnie był tym zawstydzony ${ }^{17}$. Zresztą zdawał sobie sprawę z tego, że niektóre informacje (np. dane statystyczne) były z gruntu fałszywe, bez żadnego oparcia w rzeczywistości, a on tylko zastępował jedne kłamstwa innymi ${ }^{18}$. Notabene szkoda, że z książki Orwella nie można się dokładnie dowiedzieć, czy Smith, dokonując wspomnianych zmian, starał się wiernie odtwarzać język dokumentów powstałych w okresie obowiązywania wcześniejszych wydań słowników nowomowy, czy też posługiwał się przy tym słownikiem aktualnie obowiązującym (nie od rzeczy jest też pytanie, czy te wcześniejsze wydania były w ogóle dostępne - logika podpowiada tu odpowiedź negatywną). Teoretycznie powinien był tak postępować, aby owe fałszerstwa były w jego oczach i oczach przełożonych faktycznie doskonałe. Ale w gruncie rzeczy w tamtych realiach nie miało(by) to większego znaczenia, gdyż jeśli ktokolwiek zapragnąłby badać znajdujące się w oceańskich archiwach dokumenty pod kątem ich autentyczności i spróbowałby ją zakwestionować, szybko zostałby ewaporowany. Wspomniana kwestia wydaje się tu istotna, bo jak wiadomo, język archiwaliów stanowi kod, jakim zapisywano właściwe dla danego okresu historycznego znaczenia i wyobrażenia ${ }^{19}$.

Szereg zawartych w Roku 1984 wzmianek wiedzie do konstatacji, że w Oceanii prowadzono dwojakiego rodzaju politykę w odniesieniu do dokumentacji, zależnie od tego, czy określone działania podejmowano na użytek wewnętrzny lub zewnętrzny. Ten pierwszy wiązał się ściśle z potrzebami wewnętrznej Partii i kontrolowanego przez nią aparatu przemocy, drugi natomiast dotyczył codziennej egzystencji członków Partii zewnętrznej oraz p roli, czyli nienależących do niej większości obywateli tego państwa. „Regulowanie faktów” w dokumentach z zasobu publicznych archiwów uprawnia do przeświadczenia, że dostępność nie powinna być ograniczana. Korzystanie z archiwaliów przez te ostatnie kategorie mieszkańców Oceanii z punktu widzenia władz

\footnotetext{
16 Tamże, s. 31-32.

17 Tamże, s. 111, 131.

18 Tamże, s. 32.

19 S. Marchel, dz. cyt., s. 10.
} 
partyjnych byłoby nawet pożądane, skoro ich treść w stu procentach odzwierciedlała obowiązujące poglądy i koniecznościowe wydarzenia ze sfery quasi-rzeczywistości. Zbiorów danych itp. bez znaczenia politycznego oraz tych, które mogły stać się niewygodne albo niebezpieczne - np. przepisów prawnych ${ }^{20}$ czy ksiąg adresowych umożliwiających ustalenie miejsc zamieszkania konkretnych osób i nawiązanie z nimi kontaktu ${ }^{21}$ - albo wcale nie prowadzono, albo nie były one ogólnie dostępne. Z kolei na użytek wewnętrzny tworzono, gromadzono, przechowywano i wykorzystywano zapisy dające wierny obraz rzeczywistości, które jak podpowiada logika, pozostawały niezmienione. Musiano je, w tej właśnie postaci, zachowywać przynajmniej tak długo, dopóki były użyteczne dla działań Partii, później zaś były(by) eliminowane. Zaliczały się do nich wszelkie materiały o znaczeniu operacyjno-śledczym, które na swoje potrzeby i potrzeby wierchuszki wewnętrznej Partii wytworzyli i którymi zarządzali wyłącznie agenci Policji Myśli. W pewnym koniecznym zakresie mieli też z nimi do czynienia nieszczęśnicy poddawani jej śledztwom. W książce Orwella są wątki, z których wynika, że poza tym zachowywano minimum jeden egzemplarz oficjalnych dokumentów, gazet etc. ${ }^{22}$, także mogących dopomóc $\mathrm{w}$ śledztwie lub na sądowym procesie, i to pod tym warunkiem, że w oczach oskarżonych będą miały walor autentyczności. Smithowi podczas przesłuchania pokazano nie tylko nagrania i fotografie stanowiące zapis jego inwigilacji, lecz także wycinek gazety dotyczący trzech partyjnych dysydentów. Był on identyczny z tym, który on sam niegdyś zniszczył, a który dla niego miał szczególne znaczenie, gdyż stanowił namacalny dowód ${ }^{23}$ dokonywania fałszerstw przez Partię $e^{24}$.

Uwagi poświęcone PZPR, podobnie jak w przypadku oceańskiej Partii, zacznę od kwestii jej stosunku do przeszłości, przede wszystkim jej własnej. Problem ten oświetlają m.in. wytyczne kierownictwa Wydziału Historii Partii (WHP) przy KC PZPR. Jego kierownik, Tadeusz Daniszewski, podejmując w 1949 r. polemikę z poglądami, wedle których praca komórek historycznych

20 G. Orwell, dz. cyt., s. 145.

21 Tamże, s. 114.

${ }^{22}$ Kwestia ich ewentualnej selekcji nie została przez Orwella rozwinięta.

${ }^{23}$ Był nim w tym znaczeniu, że ci podczas pokazowego procesu przyznali się do przebywania w Eurazji w charakterze szpiegów i zdrajców Oceanii udzielających jej informacji wywiadowczych, podczas gdy opublikowana w tej gazecie fotografia ukazywała ich jako członków oficjalnej delegacji partyjnej przebywającej akurat tego dnia w Nowym Jorku czyli na terenie Oceanii. Zob. tamże, s. 56-59.

24 Tamże, s. 169, 191. 
partii równała się zajmowaniu się szpargałami bez „żywotności i znaczenia” i nie miała nic wspólnego z jej rzeczywistymi potrzebami, tłumaczył:

Partia nie może żyć tylko życiem dzisiejszym i perspektywą przyszłości, ale każda partia marksistowska musi sobie uświadomić, jaki jest jej rodowód ideologiczny, co przejmuje w spuściźnie przeszłości i co odrzuca. Partia nie może wytyczać swej polityki praktycznie, nie mając określonego stosunku do przeszłości ${ }^{25}$.

Z kolei w 1957 r. w okólniku wyliczającym zadania referatów historii partii (RHP) i składnic akt przy komitetach wojewódzkich (KW) PZPR wymieniono m.in.:

Wydobywanie [...] tradycji walk okresu okupacji, walk PPR, GL i AL, ich współdziałania z RPPS [...], z SL, z BCh i z oddziałami AK - popularyzowanie tych tradycji [...] winno być przedmiotem stałej troski i systematycznej pracy RHP. Zadanie to jest szczególnie ważne wobec prób wypaczenia prawdy historycznej przez elementy reakcyjne, które usiłują siać fałszywe legendy gloryfikujące wsteczne organizacje w rodzaju NSZ, WiN-u, politycznie rehabilitować kierownictwo AK, pomniejszać historyczną rolę i wkład PPR, GL i AL ${ }^{26}$.

Uwagi te wskazują na to, że przeszłość partii przedstawiano jako ważny składnik ideowej tożsamości PZPR oraz czynnik mogący rzutować na jej aktualną linię polityczną. To implikowało podchodzenie do przeszłości ruchu robotniczego z pewnym pietyzmem, co przynajmniej częściowo przekładało się na podobny stosunek do metod i narzędzi służących jej odkrywaniu, czyli do nauki historycznej oraz partyjnych archiwów.

Rolę narzędzi wspomagających badania nad historią PZPR oraz szeroko rozumianym „ruchem rewolucyjnym” jej archiwom jednoznacznie przypisano nie później, niż w drugiej połowie lat 50. XX w., gdy ostatecznie wykrystalizowały się ich zadania. W 1958 r. kierownik Wydziału Organizacyjnego KW w Lublinie Zygmunt Zarychta, odnosząc się do sprawy przekazywania doku-

25 Stenogram z narady WHP z 15 III 1949 r., Archiwum Akt Nowych w Warszawie (dalej AAN), Polska Zjednoczona Partia Robotnicza. Komitet Centralny w Warszawie [1905-1947] 1948-1990 (dalej KC PZPR), sygn. 237/XXI-28, k. 7.

${ }^{26}$ Pismo okólne z 22 X 1957 w sprawie zadań i usprawnienia pracy RHP, Składnic Akt oraz Referatów Opieki i Pomocy przy KW PZPR, Archiwum Państwowe w Lublinie (dalej APL), Komitet Wojewódzki Polskiej Zjednoczonej Partii Robotniczej w Lublinie [1923-1974] 1975-1990 [1991] (dale KW PZPR II), sygn. 4290, k. 9. 
mentów przez niższe ogniwa partyjne wojewódzkiej Składnicy Akt, tłumaczył: „One w przyszłości będą podstawą pracy historyków nad wszechstronnym, marksistowskim opracowaniem historii rewolucyjnego ruchu robotniczego, historii naszej partii i w ogóle dziejów polskiego narodu"27. Józef Jakubowski, kierownik działu akt Polski Ludowej i archiwów KW (AKW) w Centralnym Archiwum KC PZPR (CA KC), oceniając w 1973 r. 20 lat ich działalności, podkreślił, że odgrywają ważną rolę jako placówki naukowo-badawcze pracujące nad historią całego ruchu robotniczego ${ }^{28}$. Ich funkcję definiowano czasem jako wprost służebną względem nauki historycznej, o czym świadczy wypowiedź kierownika Archiwum Zakładu Historii Partii (ZHP) przy KC, Andrzeja Janowskiego. W 1966 r. na naradzie kierowników AKW stwierdził: „W pewnym sensie, chociaż bardzo się przed tym bronimy, jesteśmy sługami nauki, jesteśmy tymi, którzy zobowiązani są dla naukowców czy też badaczy przygotować materiał dla ich prac naukowo-badawczych"29. W katalogu zadań archiwów PZPR z 1972 r. zawarto sformułowania dotyczące m.in. naukowego historycznego znaczenia jej dokumentów, wraz ze stanowiącymi na równi z nimi archiwalny zasób PZPR dokumentami partii i organizacji polskiego ruchu robotniczego od jego zarania. Wspomniano przy tym, że zasób archiwalny PZPR służy m.in. rozwojowi nauki ${ }^{30}$. Jednak nie oznaczało to „zielonego światła" ani uznania dla każdej formy uprawiania historiografii, a szczególnie dla jej niezależnego i krytycznego wobec przedmiotu badań nurtu. Można się o tym przekonać, czytając np. normatyw Wojewódzkiej Komisji Historycznej KW w Lublinie z 1949 r. dotyczący zbierania pamiętników pisanych przez działaczy ruchu robotniczego. Na marginesie charakterystyki tego źródła przewodnicząca tej komisji Stefania Socha wyraziła opinię: „nie ma obiektywnej historii, jak nie ma obiektywnej nauki. Historia jest przecież historią walki klas, więc nie ma mowy o obiektywności" ${ }^{31}$. Tego rodzaju opinie wyrastały na gruncie bolszewickiego przekonania o ideologicznym statusie nauki,

27 Pismo kierownika wydziału organizacyjnego KW do I sekretarzy KP z 1 IV 1958 r., tamże, sygn. 4090, k. 100.

${ }^{28}$ Informacja z narady kierowników AKW w dn. 22-23 XI 1973 r., tamże, sygn. 4286, k. 88.

${ }^{29}$ Informacja z narady kierowników AKW w dn. 17-18 XI 1966 r., tamże, sygn. 4076, k. 133.

30 Zadania i struktura archiwów PZPR. Projekt" (załącznik do pisma kierownika CA KC PZPR [do KW/ kierowników AKW] z 11 II 1972 r.), tamże, sygn. 4212, k. 67.

31 Pamiętniki i wspomnienia załącznik do pisma przewodniczącej WKH[P] S. Sochy do przewodniczącego Trójki Historii Partii w Kraśniku z 27 IV 1949 r., tamże, sygn. 4061, k. 9. 
będącej każdorazowo „produktem” określonych stosunków społeczno-ekonomicznych, odzwierciedleniem istniejącego układu klasowego ${ }^{32}$. Poszanowanie kierownictwa komunistycznej partii dla nauki historycznej miało zatem określone granice, a trend do traktowania jej instrumentalnie był wyraźnie dostrzegalny.

O ile jednak na manipulacje przy naukowej rekonstrukcji przeszłości, mające na celu stworzenie „kanonicznej wersji” dziejów ruchu robotniczego ${ }^{33}$, było przyzwolenie, o tyle ani archiwistom PZPR, ani ich zwierzchnikom z centralnego i wojewódzkiego kierownictwa nie przyszło do głowy fałszowanie (zwłaszcza „systemowo”) własnych dokumentów. Generalnie ceniono je w tej postaci, jaką nadali im ich twórcy. Może o tym świadczyć sposób, w jaki je opisywano. Sięgano przy tym po określenia w rodzaju: akta posiadające „trwałe znaczenie dla historii partii” ${ }^{44}$, „wymagający ochrony bezcenny materiał historyczny”35 i „niezastąpione źródło dla odtworzenia dziejów ruchu robotniczego"36, do tego dodatnio wpływające na jakość innych źródeł, np. relacji działaczy ${ }^{37}$. Między innymi z tych powodów długo stroniono od wtrącania się w sposób tworzenia w partyjnych kancelariach dokumentów, nawet jeśli potencjalnie mogłoby to zaowocować udoskonaleniem tego procesu. Gdy na jednej z narad kierowników AKW zapytano, czy archiwiści powinni ingerować $\mathrm{w}$ to, jak postępują przy tym ogniwa partyjne, padła negatywna odpowiedź. Norbert Kołomejczyk, zastępca kierownika ZHP oznajmił: „samo istnienie partyjnej służby archiwalnej obliguje niejako instytucje partii do uregulowanego obiegu dokumentów oraz do odpowiedniej formy ich sporządzania"38. Także inne wypowiedzi świadczą o tym, że ceniono walory autentycznych do-

32 Zob. R. Stobiecki, dz. cyt., s. 63.

${ }^{33}$ Por. T. P. Rutkowski, Tworzenie zrębów mitu. Działalność Wydziału Historii Partii Komitetu Centralnego Polskiej Partii Robotniczej na polu propagandy dziejów ruchu robotniczego, [w:] Polska Partia Robotnicza 1944-1948. Studia i szkice, red. M. Krzysztofiński, Rzeszów 2014, s. 272-273.

34 Pismo kierownika wydziału organizacyjnego KW do I sekretarzy KP z 1 IV 1958 r., APL, KW PZPR II, sygn. 4090, k. 100.

35 Notatka WHP z 1954 r., b.t., AAN, KC PZPR, sygn. 237/XXI-28, k. 54.

36 Pismo I sekretarza KW do I sekretarzy KM, KMG, KG, KZ PZPR [województwa lubelskiego] z 30 IV 1984 r., APL, KW PZPR II, sygn. 4282, k. 43.

37 W sprawozdaniu lubelskiego AKW z 1984 r. podkreślano to, że jego zasób służył m.in. działaczom partyjnym pracującym nad wspomnieniami - dzięki przechowywanym tam dokumentom możliwe było uzupełnianie ich luk w pamięci. Zob. Informacja o pracy AKW PZPR w Lublinie z 19 IV 1984 r., APL, KW PZPR II, sygn. 4283, k. 2.

${ }^{38}$ Informacja z narady kierowników AKW w dn. 27-28 I 1972 r., tamże, sygn. 4286, k. 69. 
kumentów przydatnych nie tylko w badaniach nad historią partii i Polski „ludowej", lecz także w pracy ideowo-wychowawczej PZPR. Kierownik lubelskiego AKW Helena Szawdzin podkreślała: „Archiwum KW to nie tylko miejsce przechowywania dokumentów i warsztat naukowy historyka, ale także ważne ogniwo frontu ideologicznego skutecznie wspierające organizacyjne przedsięwzięcia partii” ${ }^{39}$. Archiwalia wykorzystywano podczas „spotkań z dokumentem" stanowiących składową procesu nauczania i wychowania ideowego członków partii oraz młodzieży ${ }^{40}$. W odczuciu organizatorów wystaw, na których je prezentowano, przyczyniały się one do znacznego poszerzenia frontu ideologicznego oddziaływania PZPR ${ }^{41}$. Stanowiły one część instrumentarium polityki pamięci historycznej PZPR, dążącej do uzyskania nacjonalistycznej legitymizacji jej rządów ${ }^{42}$. Działająca na tym odcinku wspomniana wcześniej Szawdzin, dostrzegając u młodzieży zainteresowanie oryginalnymi dokumentami, wyciągnęła z tego następujący wniosek: „Często dokument, zwłaszcza dla dzisiejszego czytelnika, budzi większe zaufanie niż interpretacja. To widoczne zaufanie do dokumentu stwarza ogromne możliwości wykorzystania zasobów Archiwum [KW - przyp. T. C.] w pracy ideowo-wychowawczej"43. Skoro posługiwanie się autentycznymi dokumentami okazywało się na różnych płaszczyznach działalności partii zauważalnie efektywne, fałszowanie ich treści byłoby działaniem niczym nieuzasadnionym albo wręcz szkodliwym. Swe cele mogła ona osiągać bez sięgania po tak drastyczne zabiegi. Wystarczało umiejętnie dobierać i prezentować posiadane materiały.

Użyteczność dokumentów z archiwów PZPR stanowiła zasadniczą przesłankę za ich staranną ochroną przed zniszczeniem. Zdarzało się nawet, że partyjni archiwiści, dbając o powierzone im dokumenty, posuwali się do niesubordynacji wobec odgórnych poleceń dotyczących ich selektywnego niszczenia. W ten sposób zachowała się wspomniana wcześniej kierowniczka luk. 3 .

39 Informacja o pracy AKW PZPR w Lublinie z 19 IV 1984 r., tamże, sygn. 4283,

40 Służyły też upowszechnianiu rewolucyjnych tradycji regionu. Por. N. Kołomejczyk, Wojewódzkie archiwa PZPR, „Archiwa Polskiej Zjednoczonej Partii Robotniczej. Biuletyn", nr 1, 1981, s. 19.

41 Tamże.

42 Zob. T. Leszkowicz, Ostatnia ofensywa na froncie historycznym? Polityka pamięci historycznej Polskiej Zjednoczonej Partii Robotniczej w latach 1981-1986, „Dzieje Najnowsze", R. XVI, 2014, nr 2, s. 118.

43 Informacja o pracy AKW PZPR w Lublinie w latach 1957-1987 z 30 I 1988 r., APL, KW PZPR II, sygn. 4283, k. 16. 
belskiego AKW, która zignorowała wytyczne CA KC z 1971 r..$^{44}$ przewidujące wybrakowanie akt aparatu komitetów powiatowych i ocaliła w ten sposób „wiele wartościowego materiału”45. Dzięki temu nieposłuszeństwu w tym archiwum jako jedynym w kraju zachowały się akta aparatu PZPR ze szczebla powiatowego i gminnego ${ }^{46}$.

W PZPR nie traktowano nabożnie każdego archiwalnego dokumentu. Kierownictwo WHP pouczało, że członkowie partii piszący jej historię, biorąc do ręki dowolny dokument, powinni mieć do niego wyrobiony „klasowy” stosunek - przyjacielski albo wrogi. Powinni przy tym być zdolni do jednoznacznego ocenienia, czy zawiera on informacje pozytywne, tzn. związane $\mathrm{z}$,postępem historii”, czy przeciwnie - ilustruje zjawiska „obce” i „reakcyjne”. Wobec wszelkich faktów źródłowych musieli oni umieć zająć właściwe stanowisko ${ }^{47}$. Tezy te silnie kojarzą się z bolszewickimi koncepcjami historiograficznymi, wyrażającymi się zastąpieniem tradycyjnie rozumianej historii jako nauki o przeszłości z jej interpretacyjnym pluralizmem, uniwersalną i oficjalną historiozofią stroniącą od konfrontowania różnorodnych poglądów ${ }^{48}$. Te „zalecenia" udowadniają, że wyraźnie dostrzegano nie tylko korzyści, lecz także możliwe manowce i zagrożenia związane z nienależytym wykorzystywaniem dokumentacji.

Miał temu przeciwdziałać także określony tryb udostępniania archiwaliów. Z zasobu terenowych archiwów partyjnych można było korzystać wyłącznie za zgodą sekretarza KW odpowiedzialnego za propagandę lub pracę ideowo-wychowawczą. W przypadku niektórych dokumentów także inne instytucje musiały udzielić aprobaty ${ }^{49}$. Faktem jest, że udostępniano je nie tylko funkcjo-

44 Por. N. Kołomejczyk, dz. cyt., s. 15-16.

45 Informacja o pracy AKW PZPR w Lublinie w latach 1957-1987 z 30 I 1988 r., APL, KW PZPR II, sygn. 4283, k. 17-18.

46 Za tą „niesubordynację” archiwistka została w latach 80. XX w. pochwalona przez I sekretarza KW Andrzeja Szpringera. Zob. Protokół z posiedzenia zespołu historycznego Komisji KW ds. działaczy ruchu robotniczego z 14 IV 1988 r., APL, KW PZPR II, sygn. 4063, k. 2.

47 Stenogram z narady WHP z 15 III 1949 r., wypowiedź T. Daniszewskiego, AAN, KC PZPR, sygn. 237/XXI-30, k. 12.

48 R. Stobiecki, dz. cyt., s. 75.

49 W odniesieniu do materiałów nadsyłanych do KW np. przez Urzędy Spraw Wewnętrznych oraz Komendy Wojewódzkie MO, które później miały trafiały trafiać do partyjnych archiwów, w gronie kierowników AKW w 1966 r. uznano, że mają one charakter poufny i dlatego ich udostępnienie powinno być każdorazowo uzgadniane z komórkami, które je wytworzyły. Zob. Informacja z narady kierowników AKW w dn. 7-8 VI 1966 r., APL, KW PZPR II, sygn. 4076, k. 119. 
nariuszom i członkom PZPR (m.in. do celów służbowych), lecz także przedstawicielom innych organizacji oraz bezpartyjnym naukowcom i studentom. Ale nie znaczy to, że archiwa PZPR były w pełni otwarte. Wcześniej cytowany Andrzej Janowski upominał w 1960 r. kierowników AKW (wtedy nazywanych składnicami akt), aby przy udostępnianiu akt stosowali wzmożoną ostrożność, „pamiętając, że jesteśmy archiwami partii”50. Z kolei Janusz Durko, zastępca dyrektora ZHP, w 1964 r. uczulał partyjnych archiwistów na to, że udostępnianie współczesnych dokumentów partyjnych ma obok naukowego także aspekt polityczny. Implikowało to zachowanie maksymalnej ostrożności podczas realizacji tego zadania, wyrażającej się m.in. obowiązkiem każdorazowego sprawdzania przez archiwistę zawartości udostępnianych teczek „pod kątem treści i przydatności do określonego tematu”51. W zasobach partyjnych archiwów znajdowały się m.in. „archiwalia prohibitowe”, które należało zabezpieczyć, utajniając ich posiadanie za pomocą tricków ewidencji archiwalnej $^{52}$. Od 1966 r. stosowano zaostrzone kryterium polityczne wobec użytkowników wnioskujących o przekazanie im odpisów lub fotokopii archiwaliów $^{53}$. Nawet przy wydawaniu wyciągów z akt archiwa powinny kontaktować się z macierzystą organizacją partyjną wnioskodawcy i z nią wyjaśniać ewentualne wątpliwości ${ }^{54}$.

Przejdę teraz do porównania podejść i rozwiązań ze sfery historyczno-archiwalnej zaobserwowanych u oceańskiej Partii i w PZPR. Pierwsza z nich wyznawała regułę zmienności przeszłości, praktycznie oznaczającą „regulowanie" zapisów wydarzeń, poglądów etc. nieprzystających do aktualnej linii politycznej. W związku z tym nie zostawiano żadnych materialnych śladów

50 Informacja o naradzie kierowników składnic akt PZPR z 29-30 XI 1960 r., tamże, sygn. 4287, k. 25.

51 W dalszej części tego pisma ten sam autor przestrzegał „W żadnym razie nie należy udostępniać całych partii materiałów, lecz tylko wybrane, w zależności od tematu pracy i osoby korzystającej [sic!]. Materiały określone jako poufne i personalne w ogóle nie mogą być udostępniane". Pismo zastępcy kierownika ZHP do kierownika AKW z 15 II 1964 r., APL, KW PZPR II, sygn. 4213, k. 2.

52 Informacja z narady kierowników AKW w dn. 3-4 XII 1964 r., tamże, sygn. 4076, k. 87. Prostym i skutecznym rozwiązaniem miało być sporządzanie dwóch serii kart inwentarzowych: pełnej, obejmującej karty dla teczek względnie podteczek, do których miały być wkładane prohibita, przeznaczonej na potrzeby archiwum, oraz kolejnej przeznaczonej dla ogółu użytkowników, która tych akurat kart miała być pozbawiona. Tamże, k. 88.

53 Informacja z narady kierowników AKW w dn. 7-8 VI 1966 r., tamże, k. 127.

54 Informacja z narady kierowników AKW w dn. 26-27 XI 1974 r., APL, KW PZPR II, sygn. 4286, k. 95. 
mogących posłużyć zakwestionowaniu nieomylności Partii. Żaden z jej prawomyślnych członków nie popełniłby m yśl o zbrodni, dopuszczając do swego umysłu absurdalne założenie, iż zasób archiwów mógłby odzwierciedlać minione zdarzenia niezależnie od polityki Partii. Jej stosunek do dawnej rzeczywistości ${ }^{55}$ był pogardliwy i instrumentalny. Zarazem Partię cechowała obawa przed prawdziwym obrazem przeszłości, potencjalnie mogącym zachwiać jej wizerunkiem i zakłócić sprawowanie władzy. Dlatego właśnie robiła ona to, co Smitha miało przerażać bardziej od tortur i śmierci, czyli - używając jego słów - „wtykała łapę w przeszłość”, uzurpując sobie prawo do głoszenia, że określone wydarzenia nigdy nie miały miejsca ${ }^{56}$. Konsekwencją tego było też trzymanie w ukryciu dokumentów ukazujących choćby strzępy rzeczywistości oraz używanie ich wyłącznie do potrzeb aparatu władzy. Czyniło to z tych archiwów swoiste miejsca zapomnienia ${ }^{57}$. Lecz warto też dodać, że jednocześnie były one jedynymi podmiotami uprawnionymi do przechowywania dokumentów będących nośnikami określonych znaczeń. To, co znajdowało się poza ich systemem, było ex definitione skazane na zapomnienie ${ }^{58}$. Inaczej wyglądało to w przypadku PZPR. W zasadzie nie próbowała tworzyć przeszłości od nowa i nie ukrywała (przynajmniej niektórych) dawnych „błędów i wypaczeń" itp. popełnionych przez jej członków. Natomiast nagły zwrot w polityce, np. ten, jakim było ogłoszenie w 1956 r. rehabilitacji Komunistycznej Partii Polski rozwiązanej z powodu jej rzekomego zinfiltrowania przez wywiad II Rzeczypospolitej, był bodźcem do zbierania dokumentacji - w tym przypadku mającego na celu przywrócenie KPP dobrego imienia i wyeksponowania jej dokonań ${ }^{59}$. Była w tym też intencja odtworzenia prawdziwego i pełnego obra-

55 Słowo „rzeczywistość” oznaczające to, co realnie istnieje, synonimiczne z terminami: prawda, autentyczność, dokumentalność, pewność czy świat obiektywny (por. Synonim.net, http://synonim.net/synonim/rzeczywisto\%C5\%9B\%C4\%87, dostęp: 20 IV 2015 r.), jako zbyt abstrakcyjne i potencjalnie niebezpieczne, najprawdopodobniej zniknęło(by) z języka, którym posługiwali się mieszkańcy Oceanii po wydaniu któregoś z kolei słownika nowomowy.

56 G. Orwell, dz. cyt., s. 27.

57 Por. H. Ciechanowski, Archiwum jako miejsce zapomnienia, [w:] Toruńskie konfrontacje archiwalne, t. 4: Nowa archiwistyka - archiwa i archiwistyka $w$ ponowoczesnym kontekście kulturowym, red. W. Chorążyczewski, W. Piasek i A. Rosa, Toruń 2014, s. 48 i n.

58 Por. S. Marchel, dz. cyt., s. 15.

59 Podkreślono przy tym, że „ze względu na ważność i odpowiedzialność przed przyszłymi pokoleniami musimy do tej pracy zebrać się z większym zapałem, tym bardziej, że w miarę oddalania się od tych faktów ulatniają się one z pamięci, a co gorsze i uczestnicy w miarę upływu lat też nam ubywają". Zob. Referat bez tytułu wygłoszo- 
zu wydarzeń związanych z przeszłością partii, nad którymi przez długi czas wisiała kurtyna zapomnienia i niedomówień. Byli działacze tej partii wprost żądali od aktualnego kierownictwa PZPR zapoznania się z jej faktyczną przeszłością ${ }^{60}$. Choć w PZPR dobrze zdawano sobie sprawę, że przeszłość może być niewygodna (dlatego uciekano się do manipulowania historiografią), nie obawiano się jej jednak tak dalece, jak w oceańskiej Partii. Mniej chwalebnych wydarzeń nie zamiatano również hurtem pod dywan, a od kierownictwa partii jej „doły” oczekiwały nie tego, że będzie ono oficjalnie obwieszczać, jak faktycznie wyglądała przeszłość - jak było w Oceanii - lecz spodziewano się, że dołoży ono starań, aby ją rzetelnie poznać i rozpropagować. Może to wynikać stąd, że zarówno warunki ustrojowo-polityczne, w jakich funkcjonowała PZPR, jak i osiągnięty przez nią etap rozwoju ideologicznego znacząco odbiegały od tego, jak przedstawiało się to w przypadku Oceanii i jej jedynej siły politycznej - Partii.

Obie partie zajmowały określony stosunek wobec przeszłości. Dla jego zobrazowania odwołam się do propozycji kategoryzacji przyczyn zainteresowania przeszłością opisanych przez Jerzego Maternickiego. W przypadku PZPR można uchwycić występowanie splotu kilku motywów. W raczej ograniczonym zakresie chodziło o jeden z motywów typu poznawczego, tj. genetyczny, wiążący się z upatrywaniem w znajomości historii środka służącego lepszemu rozumieniu teraźniejszości ${ }^{61}$. Bez wątpienia przeważały motywy polegające na łączeniu znajomości dziejów z określonymi korzyściami praktycznymi. $\mathrm{Z}$ praktyczną motywacją wiąże się postrzeganie historii przez pryzmat aktualnych problemów społecznych, prawno-ustrojowych, politycznych, ideologicznych lub wychowawczych, a rezultatem takiego podejścia jest wyraźnie wytyczony zakres zainteresowań historycznych, taki, a nie inny dobór fak-

ny na naradzie członków powiatowych Trójek Historii Partii, 28 VI 1956 r., APL, Komitet Wojewódzki Polskiej Zjednoczonej Partii Robotniczej w Lublinie [1883] 1948-1975 [1990], sygn. 2736, k. 26.

60 Protokół z plenarnego posiedzenia Komisji Opieki i Pomocy przy KM PZPR w Lublinie z 12 I 1959 r., APL, Komitet Miejski Polskiej Zjednoczonej Partii Robotniczej w Lublinie 1948-1990, sygn. 3565, k. 2. Chodzi o wypowiedź Jana Wójcika, niezadowolonego z poziomu i treści referatów z sesji z okazji 40 rocznicy powstania KPP, który wyraził pod adresem I sekretarza KW PZPR w Lublinie Władysława Kozdry zdziwienie, że jako gospodarz sesji nie dołożył on należytych starań, aby także samemu poznać autentyczną historię „ruchu rewolucyjnego” na Lubelszczyźnie.

61 Por. J. Maternicki, Wielokształtność historii. Rozważania o kulturze historycznej i badaniach historiograficznych, Warszawa 1990, s. 30. 
tów oraz sposoby ich wyjaśniania i oceny ${ }^{62}$. Spośród pięciu głównych motywów praktycznych w przypadku PZPR do głosu dochodziły, w różnym nasileniu, motywy technologiczny, ideologiczny, propagandowy i dydaktyczny. W niewielkim stopniu mogło chodzić o pierwszy z nich, oparty na przekonaniu o powtarzalności historii - historią "nauczycielką życia” - i wiążący się z szukaniem w dziejach gotowych wzorów postępowania i/lub materiału do przemyśleń ${ }^{63}$. Przede wszystkim chodziło motywację ideologiczną, odwołującą się do poszukiwania w przeszłości potwierdzeń wyznawanych wartości, tj. państwo, klasa itd., względnie szukania więzi ideowych łączących określone wspólnoty (np. partię). Wydaje się to tym bardziej oczywiste, gdy sobie uświadomimy, że podejście ideologiczne zazwyczaj jest nacechowane brakiem umiaru, jednostronnością, schematycznymi ocenami oraz wyodrębnianiem sfery spraw bliskich własnej wspólnocie i sfery spraw jej obcych, dotyczących innych wspólnot, co nierzadko wiedzie do stosowania dwóch różnych miar w ocenie zjawisk historycznych: innego widzenia spraw „bliskich” i „obcych”. W sposób oczywisty reprezentowany był też motyw propagandowy, pokrewny ideologicznemu, ale powiązany bardziej z osiąganiem doraźnych efektów politycznych za pomocą historycznych argumentów, choć motywacja propagandowa może też być bardziej „systemowa”, wówczas, gdy uwidacznia się planowe i długotrwałe działanie na rzecz związania odbiorcy propagandy z danym ruchem ${ }^{64}$. PZPR należy też przypisać dydaktyczne motywy zainteresowań historycznych, z uwagi na hołdowanie przekonaniu o roli historii $\mathrm{w}$ „socjalizacji" młodzieży, przysposobieniu jej do myślenia kategoriami życia społecznego - wychowania wzorowego obywatela, człowieka itd. Niewątpliwie usiłowała też za pomocą historii oddziaływać na dorosłą część społeczeństwa, kształtując jego świadomośćc5. Jak zauważył Maternicki, w roli edukatorów występują m.in. organizacje społeczne i polityczne ${ }^{66}$. Innych motywów, takich jak kulturologiczny, antropologiczny, ludyczny czy artystyczny, zdecydowanie nie należy przypisywać PZPR ${ }^{67}$. W przypadku oceańskiej Partii, która, jak wspomniałem, przeszłości się obawiała, a zarazem gardziła nią i traktowała ją in-

62 Por. tamże, s. 31.

63 Por. tamże, s. 33.

${ }^{64}$ Por. tamże, s. 36. Ów autor podkreślał, że każdy autentyczny ruch polityczny dąży do stworzenia własnej ideologii historycznej, pełniącej służebną funkcję wobec głoszonych przez siebie idei. Tamże, s. 37.

65 Por. tamże, s. 40-42.

66 Tamże, s. 42.

67 Por. tamże, s. 34, 42-44. 
strumentalnie, w grę mogły(by) wchodzić tylko - i to w ograniczonym zakresie - motywy propagandowe i dydaktyczne.

Odmienne podejście do przeszłości przekładało się też na to, że w obu modelach całkowicie inaczej podchodzono do historiografii. W Oceanii nie było w ogóle gruntu do jej uprawiania. Partię bardziej niż czyny (res gestae) osób, a zwłaszcza badania historyczne jako sposób ich ustalania, interesowały ich myślii68. Natomiast PZPR, skoncentrowanej raczej na czynach, nieobce było inicjowanie i wspieranie badań historycznych, choć obiektywizm dokonywanych ustaleń badawczych nierzadko można zakwestionować. Wytworzyła ona wyspecjalizowane struktury, do których zaliczają się też archiwa, parające się historią jej samej i całego ruchu robotniczego.

Tym, co można by uznać za wspólną cechę archiwów podlegających Partii i archiwów PZPR było to, że informacje zawarte w dokumentach trafiających do ich zasobów i w nich przechowywanych dzięki temu właśnie „stawały się prawdą" i mogły uchodzić za autentyczne ${ }^{69}$. Ale w tym pierwszym przypadku „prawda” stanowiła kategorię zmienną wskutek płynności zasobu oceańskich archiwów - rezultatu dokonywanego „regulowania”70. Dzięki temu te ostatnie - pomijam tajną dokumentację w całkowitej gestii Policji Myśli - mogły(by) mieć charakter w pełni jawnych, otwartych placówek. Pod tym względem archiwa Oceanii nieco różniły(by) się od archiwów PZPR z ich poufnymi działami i systemem reglamentowania dostępu do znajdujących się w nich dokumentów. Ta ostrożność paradoksalnie wydawała świadectwo prawdziwości informacji w nich zawartych.

Przywoływana przy opisie archiwów Oceanii praktyka „regulowania” ich zasobu odróżnia je od archiwów PZPR także w wymiarze procesów ich formowania się. Te ostatnie, podobnie jak inne „normalne” archiwa, można bezspornie sytuować w obrębie ostatniej fazy przebiegu procesów archiwotwór-

68 G. Orwell, dz. cyt., s. 174.

69 Por.: tamże, s. 35; M. Hlebionek, Praecipum archivi effectus est probatio ac fides rei gesta publica. Krytyka autentyczności $i$ wiarygodności materiałów archiwalnych $w$ najstarszych traktatach archiwistycznych, [w:] Silva rerum opera historica, diplomatica et archivistica continens, Andreae Tomczak dedicata, red. W. Chorążyczewski, M. Hlebionek, Toruń-Warszawa 2012, s. 133, 136.

70 Aby jawnie nie przyznawać się do fałszerstw każdy pracownik departamentu archiwów pracował indywidualnie, a nie w zespole. Nie wykluczało to ewentualności jednoczesnego (choć z osobna) pracowania przez nich nad tymi samymi sprawami. Por. G. Orwell, dz. cyt., s. 35. 
$\mathrm{czych}^{71}$. W uproszczeniu obejmowały one sporządzenie $\mathrm{w}$ danym ogniwie partii dokumentów, łączenie ich $\mathrm{z}$ innymi $\mathrm{w}$ jednostki kancelaryjne $\mathrm{w}$ toku załatwiania spraw (proces aktotwórczy), a następnie tracenie przez nie bieżącej przydatności dla ich twórcy i ich archiwizację. Tą, zależnie od tego, czy akta miały znaczenie historyczne bądź były pozbawione tego waloru, kończyło albo ich wieczyste przechowywanie w centralnym lub wojewódzkim archiwum PZPR albo wydzielenie i zniszczenie po upływie określonego terminu. Archiwa w Oceanii właściwie nie uczestniczyły w zachodzących linearnie procesach archiwotwórczych ${ }^{72}$. Natomiast nieco do nich podobne procesy należałoby je chyba nazwać quasi-archiwotwórczymi - w których brały(by) one udział, cechowała(by) możliwość „przeskakiwania” z ich faz późniejszych do uprzednio zakończonych (np. poprzez wyłączanie niektórych dokumentów z już uformowanych akt spraw), a nawet płynne przechodzenie od fazy zakończonej zniszczeniem danego dokumentu do fazy jego (ponownej) kreacji! Typową praktyką była(by) też realizacja konkretnych procesów quasi-archiwotwórczych zupełnie od nowa. Dodajmy, że w przypadku każdego kolejnego powtórzenia takowego procesu udział odbiorcy prymarnego, oczywisty w normalnych warunkach przebiegania procesu archiwotwórczego, byłby zupełną fikcją.

Dotychczasowe porównania zdradzają znacznie częstsze występowanie mniej lub bardziej wyraźnych różnic pomiędzy obydwoma modelami. Szukając podobieństw, można stwierdzić, że zarówno archiwom Oceanii, jak i analogicznym komórkom PZPR można przypisać prowadzenie działalności dokumentacyjnej, rozumianej jako wyszukiwanie dokumentów do określonych tematów, na poparcie pewnych tez, względnie jako aktywne uzupełnianie zasobu archiwum o niedostępne dla niego w zwykłym trybie gromadzenia archiwaliów dokumenty ${ }^{73}$. W departamencie archiwów Ministerstwa Prawdy największy był dział „researcherski” lokalizujący i usuwający wszystkie dokumenty i gazety wymagające podmienienia i zniszczenia ${ }^{74}$, w reakcji na każ-

71 Na ten temat zob. zwłaszcza B. Ryszewski, Problemy i metody badawcze archiwistyki, Toruń 1985, s. 86-89.

${ }^{72}$ Nie wiem, czy w tym kontekście w ogóle można używać tej nazwy. W najlepszym razie należałoby je uznać za bardzo mocno „zmodyfikowane” albo inaczej na to patrząc, po prostu zakłócane.

73 Szerzej na ten temat T. Grygier, Współczesne zadania dokumentacyjne archiwów, „Archiwa, Biblioteki i Muzea Kościelne”, t. 40-42, 1980-1981.

74 G. Orwell, dz. cyt., s. 32. 
dą zmianę w sferze polityki albo w związku z ewaporowaniem człowieka ${ }^{75}$. Była to działalność dokumentacyjna à rebours - choć może właściwiej byłoby ją nazwać swoiście „źródłotwórczą”, skoro chodziło nie tyle o zniszczenie dokumentu czy wymazanie określonej informacji lub danych, ile o uformowanie całkiem nowej postaci źródła. Archiwa PZPR i komórki zajmujące się jej historią prowadziły natomiast klasyczną działalność dokumentacyjną. Polegała na uzupełnianiu zasobu aktowego o materiały wytworzone w innym czasie lub warunkach od tych, w jakich powstawała bieżąca dokumentacja instancji i aparatu partyjnego PZPR. W jej ramach zbierano dokumenty ideowych poprzedniczek PZPR, fotografie, materiały ulotne, spuścizny działaczy, prasę, dokumentację procesów i śledztw z udziałem komunistów w okresie międzywojennym, a także materiały innych organizacji, w tym nawet wrogich lub opozycyjnych.

Napisaniu tego artykułu przyświecał zamiar zestawienia ukazanego w Roku 1984 podejścia rządzącej Oceanią Partii do przeszłości, historii i w szczególności archiwów z analogicznym podejściem PZPR, głównie w celu uzyskania kolejnej warstwy informacji na temat jej działalności w tym właśnie zakresie. Interesowało mnie sprawdzenie tego, na ile literacka wizja pewnego fragmentu ustroju fikcyjnego totalitarnego państwa okazałaby się zbieżna z tym, co w podobnej dziedzinie można by przypisać głównej sile politycznej PRL. Jak podkreślał Bronisław Baczko, wszystkie mechanizmy systemu władzy opisanego w wymienionej książce - dodam, że zaliczały się do nich także tamtejsze archiwa - służyły „zniewoleniu myśli i wyobraźni, ich spustoszeniu na skutek odcięcia od źródeł, które mogłyby je zasilić. Sprawność systemu polega w szczególności na tym, że jego mechanizmy uniemożliwiają wszelkie wyobrażenia społeczeństwa innego niż istniejące, wszelką myśl o takim społeczeństwie. Stąd też nieustanne przystosowywanie przeszłości do teraźniejszości"76. Czy cokolwiek z tego, co napisano odnośnie do koncepcji i praktyk związanych z archiwami PZPR, pozwala na uchwycenie między nimi silnej analogii? W przekonaniu o konieczności udzielenia negatywnej odpowiedzi na to pytanie, ośmielam się twierdzić, że generalnie mamy tu do czynienia z dwoma odmiennymi stylami postępowania. Liczbę zbieżności należy uznać za znikomą. Czego to dowodzi? Być może tego, że jakkolwiek by oceniać rozwiązaną 29 I 1990 r. partii, doszukiwanie się w tej jednej kwestii -

75 Zarządzano wówczas usuwanie nawet najdrobniejszych zapisów tego, co on robił, poczynając od adnotacji w księgach metrykalnych. Zob. G. Orwell, dz. cyt., s. 17.

76 B. Baczko, Orwell, Sotżenicyn , „Przegląd Polityczny”, nr 43, 2000, s. 90. 
w jej podejściu do materii historyczno-archiwalnej - wyraźnych podobieństw (nie mówiąc już o inspiracjach) do opisów znanych z książki Orwella byłoby chybionym posunięciem.

\section{Archiwalia}

Archiwum Akt Nowych w Warszawie

- Polska Zjednoczona Partia Robotnicza. Komitet Centralny w Warszawie [1905-1947] 1948-1990

Archiwum Państwowe w Lublinie

- Komitet Miejski Polskiej Zjednoczonej Partii Robotniczej w Lublinie 1948-1990

- Komitet Wojewódzki Polskiej Zjednoczonej Partii Robotniczej w Lublinie [1883] 1948-1975 [1990] Komitet Wojewódzki Polskiej Zjednoczonej Partii Robotniczej w Lublinie [1923-1974] 1975-1990 [1991]

\section{Literatura}

Baczko B., Orwell, Soł̇̇enicyn, „Przegląd Polityczny”, nr 43, 2000, s. 86-93.

Ciechanowski H., Archiwum jako miejsce zapomnienia, [w:] Toruńskie konfrontacje archiwalne, t. 4: Nowa archiwistyka - archiwa i archiwistyka $w$ ponowoczesnym kontekście kulturowym, red. W. Chorążyczewski, W. Piasek i A. Rosa, Toruń 2014.

Grygier T., Współczesne zadania dokumentacyjne archiwów, „Archiwa, Biblioteki i Muzea Kościelne", t. 40, 1980.

Grygier T., Wspótczesne zadania dokumentacyjne archiwów (II), „Archiwa, Biblioteki i Muzea Kościelne", t. 41, 1980.

Grygier T., Współczesne zadania dokumentacyjne archiwów (III), „Archiwa, Biblioteki i Muzea Kościelne”, t. 42, 1981.

Hlebionek M., Praecipum archivi effectus est probatio ac fides rei gesta publica. Krytyka autentyczności $i$ wiarygodności materiałów archiwalnych $w$ najstarszych traktatach archiwistycznych, [w:] Silva rerum opera historica, diplomatica et archivistica continens, Andreae Tomczak dedicata, red. W. Chorążyczewski, M. Hlebionek, Toruń-Warszawa 2012.

Horst W., Kancelarie i archiwa Centralnego Komitetu Wykonawczego Polskiej Partii Socjalistycznej, Komitetu Centralnego Polskiej Partii Robotniczej i Komitetu Centralnego Polskiej Zjednoczonej Partii Robotniczej (1944-1990), Warszawa 2006.

Kołomejczyk N., Wojewódzkie archiwa PZPR, „Archiwa Polskiej Zjednoczonej Partii Robotniczej. Biuletyn", nr 1, 1981.

Leszkowicz T., Ostatnia ofensywa na froncie historycznym? Polityka pamięci historycznej Polskiej Zjednoczonej Partii Robotniczej w latach 1981-1986, „Dzieje Najnowsze", R. XVI, 2014, nr 2.

Magier D., Archiwum Komitetu Wojewódzkiego PZPR w Białej Podlaskiej, „Archiwa Kancelarie - Zbiory", nr 1 (3), 2010. 
Marchel S., „Przez dziurkę od klucza...” Rozważania na marginesie badań nad rolą archiwów $w$ procesie ksztattowania interpretacji historycznej, [w:] Otwarty skarbiec pamięci. Studia Zespołu Archiwum Państwowego w Opolu zebrane z okazji 60-lecia powstania instytucji, cz. 2: Bogactwo zasobu i przygoda poznania, red. M. Lenart, Opole 2013.

Maternicki J., Wielokształtność historii. Rozważania o kulturze historycznej i badaniach historiograficznych, Warszawa 1990.

Orwell G., Rok 1984, przeł. T. Mirkowicz, Warszawa 1988

Rutkowski T. P., Tworzenie zrębów mitu. Działalność Wydziału Historii Partii Komitetu Centralnego Polskiej Partii Robotniczej na polu propagandy dziejów ruchu robotniczego, [w:] Polska Partia Robotnicza 1944-1948. Studia i szkice, red. M. Krzysztofiński, Rzeszów 2014.

Ryszewski B., Problemy i metody badawcze archiwistyki, Toruń 1985.

Stobiecki R., Bolszewizm a historia. Próba rekonstrukcji bolszewickiej filozofii dziejów, Łódź 1998.

\section{Summary}

Archives of Oceania in George Orwell's Nineteen Eighty-Four and archives of the Polish United Workers' Party. An attempt of comparative analysis

Similarities between totalitarian state Oceania ruled by the Party in Nineteen Eighty-Four to communist rule in Europe and outside of it provoke comparisons. They enable to obtain additional knowledge not only about the book, but also about the system; so it is in the case of my article. In this article I concentrated on the issue of archives and, partly, past and history, illustrated by information from the G. Orwell's book and archival materials of the Polish United Workers' Party. In Oceania the past was a changing category as a result of full control of all elements linking it to the present (press, books, documents etc.), which led to strengthening the Party's rule. Documents stored in archives were constantly swapped, so they conform what the Party was claiming at the time. In that situation access to the fabricated studies and sources must have been free. But objective historiography could not exist, even if "historical" books were published. In turn, for the PUWP that ruled in Poland, accomplishments of the party and its predecessors were important for the ideology and legitimizing its authority. The party discerned the benefits of initiating historical research (not necessarily fully objective) and preserving authentic documents in its archives, which could be used in the research and propaganda. But the holdings of the party's archives were not accessible for everyone. For example, documents depicting "not progressive" phenomena were rationed. Comparing approach to this issue of the Oceanian Party and of the PUWP shows, that they actually had completely different visions and ways of acting. It leads to a conclusion, that the PUWP hardly resembled similar strands described by G. Orwell, looking on the archival issues. 
